Available online on 15.07.2018 at http://jddtonline.info
Journal of Drug Delivery and Therapeutics
Open Access to Pharmaceutical and Medical Research
$\begin{gathered}\text { @ 2011-18, publisher and licensee JDDT, This is an Open Access article which permits unrestricted non- } \\ \text { commercial use, provided the original work is properly cited }\end{gathered}$

Open Access

Research Article

\title{
FORMULATION AND EVALUATION OF FLOATING TABLET FOR INDOMETHACIN
}

\author{
Yashpal Singh Chauhan*, Udichi Kataria, Ashok Dashora \\ Geetanjali Institute of Pharmacy, Udaipur, Rajasthan, India
}

\begin{abstract}
The present study was aimed to formulate and evaluate floating tablets of indomethacin by wet granulation method. Indomethacin is used as a potent anti-inflammatory drug with prompt anti pyretic action, mainly used for the treatment of osteoarthritis with half-life of $4.5 \mathrm{hrs}$. Indomethacin is stable in neutral or slightly acidic media. In this study, excipients like HPMC 5cps, sodium bi carbonate were incorporated in a nine different concentrations (F1-F9) along with other excipients (PVP K30, lactose, talc, and magnesium stearate) to formulate floating tablets by wet granulation method. Then all the nine formulations were evaluated for uniformity of weight, hardness, thickness, friability test, floating lag time, drug content, dissolution studies and stability studies. The dissolution profile of trial-6 (formulation 6) was observed to be better than other formulations. In trial-6 indomethacin was formulated as a floating tablet by using HPMC 5cps (120 mg) as a matrix forming polymer and sodium bi carbonate (40 mg) as a gas generating agent. Trial-6 formulation showed a good dissolution profile for a controlled period of time which was noticed to be as $97.78 \%$ at the end of $12^{\text {th }}$ hour. Thus, it can be concluded that the floating drug delivery system of indomethacin using the appropriate polymers in right amount may enhance the activity of the drug by prolonging the gastric residence time or reducing the floating lag time.
\end{abstract}

Keywords: Indomethacin, HPMC 5cps, Sodium bi carbonate.

Article Info: Received 10 June, 2018; Review Completed 14 July 2018; Accepted 16 July 2018; Available online 17 July 2018

Cite this article as:

Chauhan YS, Kataria U, Dashora A, Formulation and evaluation of floating tablet for indomethacin, Journal of Drug Delivery and Therapeutics. 2018; 8(4):338-345 DOI: http://dx.doi.org/10.22270/jddt.v8i4.1811

*Address for Correspondence:

Yashpal Singh Chauhan, Geetanjali Institute of Pharmacy, Udaipur, Rajasthan, India

\section{INTRODUCTION}

Gastric transit time is valuable asset for dosage forms, which reside in the stomach for a long period of time than conventional dosage form. Conventional oral dosage forms (such as tablets, capsules) provide specific drug concentration in systemic circulation without offering any control over drug delivery and also cause great fluctuations in plasma drug levels. ${ }^{1,2}$ Many attempts have been made to develop sustained release preparations with extended clinical effects and reduced dosing frequency. ${ }^{3,4}$ One of the such approach can be floating systems which are low density systems that have sufficient buoyancy to float over the gastric contents and remain in the stomach for a prolonged period. While the system floats over the gastric contents, the drug is released slowly at the desired rate, which results in increased gastro-retention time and reduces fluctuation. ${ }^{5,6}$ Floating drug delivery systems have an advantage to reduce the dose frequency and improves patient compliance. It thus improves the therapy. ${ }^{7}$ The fluctuations in plasma drug concentration are minimized, and thus concentration-dependent adverse effects that are associated with peak concentrations can be prevented. This feature is of special importance for drugs with a narrow therapeutic index. That makes it possible to obtain certain selectivity in the elicited pharmacological effect of drugs that activate different types of receptors at different concentrations. ${ }^{8,9}$ Floating drug delivery systems reduces the drug concentration fluctuation over a critical concentration and thus enhances the pharmacological effects and improves the clinical outcomes. ${ }^{10}$ 


\section{MATERIALS AND METHODS}

Indomethacin was obtained as gift sample from sigma aldrich chemicals pvt. Ltd. Bangalore, India. Different polymers and excipients like lactose, hydroxy propyl methyl cellulose 5cps, Sodium bicarbonate, PVPK30, Talc, Magnesium stearate were purchased from Central drug house Ltd. New Delhi, India. All other ingredients used were of laboratory grade.

\section{Preformulation studies:}

The parameters like melting point, IR spectra, angle of repose, bulk density, tapped density, Hausner's ratio were determined as the part of preformulation studies. ${ }^{11}$

\section{Drug-excipient compatibility studies:}

Compatibility studies were carried out to know the possible interactions between indomethacin and excipients used in the formulation. Physical mixtures of drug and excipients were prepared to study the compatibility using the Infra Red spectrophotometer. ${ }^{12}$.

\section{Preparation of indomethacin floating tablet:}

All the ingredients (except glidants and lubricant) as shown in Table1 were weighed separately, mixed thoroughly in poly bag for 10 minutes to ensure uniform mixing and the mixture was passed through sieve no.60. Granulation was done with a solution of calculated quantity of PVP K30 in sufficient isopropyl alcohol. The wet mass was passed through sieve no. 12 , and dried at $75^{\circ} \mathrm{C}$ for 2 hours. The dried granules were sized by sieve no. 18 and mixed with magnesium stearate and talc. The blend thus obtained was compressed $(8 \mathrm{~mm}$ diameter, flat punches) using a single station tablet press machine (Cip, Ahmadabad). ${ }^{13}$

Table 1: Formulation batches of indomethacin floating tablet by wet granulation method.

\begin{tabular}{|l|l|l|l|l|l|l|l|l|l|l|}
\hline S.NO. & Ingredients (mg) & F1 & F2 & F3 & F4 & F5 & F6 & F7 & F8 & F9 \\
\hline 01 & Indomethacin & 75 & 75 & 75 & 75 & 75 & 75 & 75 & 75 & 75 \\
\hline 02 & HPMC 5cps & 60 & 80 & 120 & 60 & 80 & 120 & 60 & 80 & 120 \\
\hline 03 & Sodium bicarbonate & 20 & 20 & 20 & 40 & 40 & 40 & 50 & 50 & 50 \\
\hline 04 & PVP K30 & 20 & 20 & 20 & 20 & 20 & 20 & 20 & 20 & 20 \\
\hline 05 & Lactose & 30 & 30 & 30 & 30 & 30 & 30 & 30 & 30 & 30 \\
\hline 06 & Talc & 5 & 5 & 5 & 5 & 5 & 5 & 5 & 5 & 5 \\
\hline 07 & Magnesium stearate & 10 & 10 & 10 & 10 & 10 & 10 & 10 & 10 & 10 \\
\hline
\end{tabular}

\section{Evaluation of floating tablets:}

1. Uniformity of weight: Twenty tablets were weighed individually and the average weight was determined. The percentage deviation was calculated and checked for weight variation as per $\mathrm{IP}^{14}$. Deviation of weight variation is given in table 2 .

\section{Table 2: \% Deviation for Weight Variation}

\begin{tabular}{|c|c|}
\hline Average Weight of tablet (mg) & \% Deviation \\
\hline $80 \mathrm{mg}$ or less & 10 \\
\hline $80 \mathrm{mg}$ to $250 \mathrm{mg}$ & 7.5 \\
\hline $250 \mathrm{mg}$ or more & 5 \\
\hline
\end{tabular}

2. Hardness: Hardness or tablet crushing strength (fc ), is the force required to break a tablet in a diametric Compression. This compression force was measured using Monsanto tablet hardness tester for all the batches ${ }^{15}$. It is expressed in $\mathrm{kg} / \mathrm{cm}^{2}$.

3. Thickness: Thickness of tablets is important for uniformity of tablet size. Thickness was measured using Vernier Calipers on 3 randomly selected samples. ${ }^{16}$

\section{Friability test:}

Friability is the measure of tablet strength. Roche friabilator was used for testing the friability using the following procedure. Twenty tablets were weighed accurately and placed in the tumbling apparatus that revolves at $25 \mathrm{rpm}$ dropping the tablets through a distance of six inches with each revolution. After 4 minutes, the tablets were weighed and the percentage loss in tablet weight was determined using the below given formula. ${ }^{17}$

$$
=\frac{\text { Initial wt. of tablets (W1) - Final wt. of tablets (W2) }}{\text { Initial wt. of tablets (W1) }} \times 100
$$

\section{Floating lag time:}

The lag time was carried out in beaker containing 250 $\mathrm{ml}$ of $\mathrm{pH} 1.2$ buffer solution as a testing medium maintained at $37^{\circ} \mathrm{C}$. The time required for the tablet to rise to the surface and float was determined as floating lag time in minutes. ${ }^{18}$

\section{Drug content:}

Five tablets were weighed individually, and powdered. The drug was extracted in $\mathrm{pH} 1.2$ and the solution was filtered through whatman filter paper. The absorbance was measured at $237 \mathrm{~nm}$ after suitable dilution using a shimadzu UV spectrophotometer. ${ }^{19}$

\section{Dissolution studies:}

The release rate of indomethacin from floating tablets was determined using USP Dissolution Testing Apparatus II (Paddle type). The dissolution test was performed using $900 \mathrm{ml}$ of $\mathrm{pH} 1.2$ buffer solution, at 37 $\pm 0.5^{\circ} \mathrm{C}$ and $50 \mathrm{rpm}$. Aliquot volume was withdrawn from the dissolution apparatus hourly for $12 \mathrm{~h}$, and the samples were replaced with fresh dissolution medium. After filtration and suitable dilution the amount of drug release was determined from the calibration curve. ${ }^{20}$ 
Details of Dissolution Test:

1. Apparatus

2. Volume of medium

3. Temperature

4. Paddle Speed

5. Dissolution medium used: $\mathrm{pH} 1.2$ buffer solution

6. Aliquot taken at each time interval: $5 \mathrm{ml}$

\section{Stability studies of the standard formulations:}

Stability testing of drug products begins as a part of drug discovery and ends with the demise of the compound or commercial product. To assess the drug and formulation stability, the stability studies were carried out on the one most satisfactory formulation as per ICH guidelines Q1C. ${ }^{21}$ The most satisfactory formulation $\mathrm{F} 6$ was sealed in aluminum packaging and was kept in humidity chamber maintained at $35 \pm 2{ }^{\circ} \mathrm{C} /$ $60 \pm 5 \% \mathrm{RH}$ and $40 \pm 2{ }^{\circ} \mathrm{C} / 75 \pm 5 \% \mathrm{RH}$ for 3 months. It was then evaluated for various parameters to check the stability and efficacy of the product.

\section{RESULT AND DISCUSSION}

The prepared floating tablets were evaluated for various physical properties. The physical attributes of the floating tablets were found to be satisfactory. Typical tablets defects were not observed. Preformulation studies were done as mentioned in methods. The melting point was observed to be $\left(157^{\circ} \mathrm{C}-159^{\circ} \mathrm{C}\right)$ which shows that the indomethacin drug was pure. Formulation of floating tablets was prepared as per wet granulation method. The prepared tablets were then evaluated for parameters such as weight variation, Hardness, friability and thickness, diameter, Floating lag time.

To check the purity of drug, IR spectrum of Indomethacin was taken on Jasco FTIR 4000. The spectra shows characteristic peaks of Indomethacin similar to the standard spectra given in the instrumental analysis. The IR spectrum is given in the figure $\mathbf{1}$, and drug peaks are given in table 3 .

To check the interaction between drug and Excipients, used in the formulations, IR studies were performed. In IR study, it was found that all the prominent peaks which were present in individual graphs of Indomethacin were also present in IR of physical mixture between drug and Excipients. Thus we can say that there was no significant interaction between drug and Excipients. The drug and excipients spectrum are given in the figure 2 and peaks are given in table 4 .

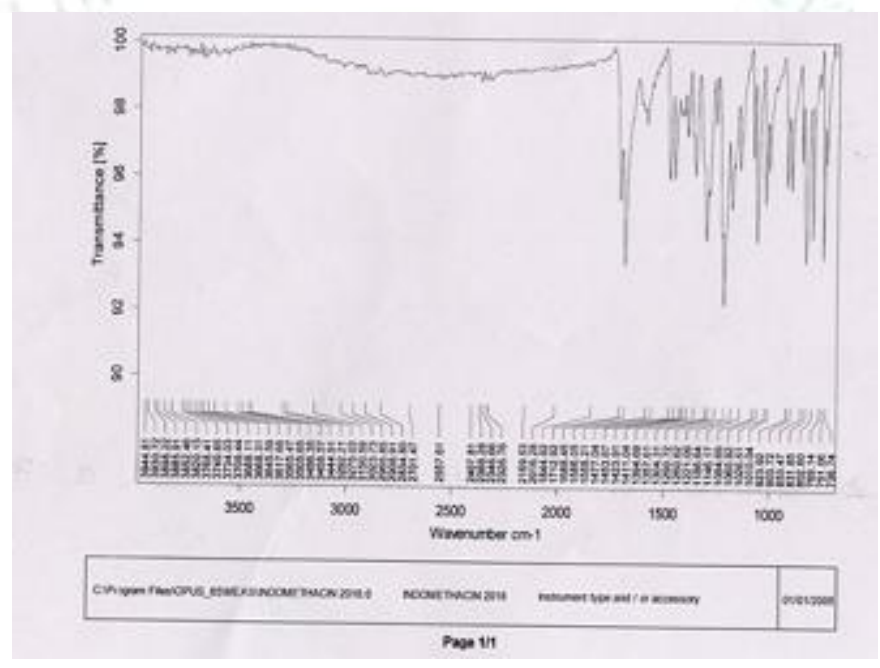

Figure 1: FTIR Spectra of Indomethacin

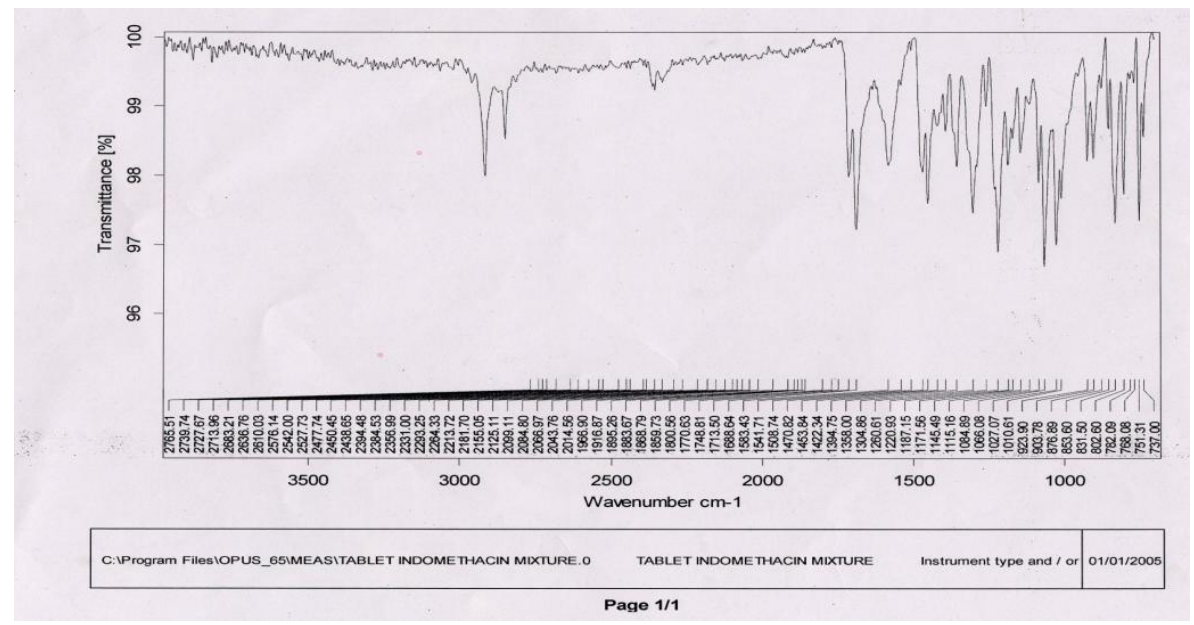

Figure 2: FTIR Spectra of Tablet of indomethacin and excipients. 
Table 3: Characteristic IR absorption peaks of functional groups in Indomethacin

\begin{tabular}{|c|c|c|c|}
\hline Sr. No. & Particulars & Functional Groups & Characteristic Peaks(cm $\left.{ }^{-1}\right)$ \\
\hline \multirow{4}{*}{1} & Indomethacin & C-Cl stretching & 802 \\
\cline { 3 - 4 } & & C-O stretching ether & 1260,1065 \\
\cline { 3 - 4 } & & O-H(carboxy) str. & 2965,3275 \\
\cline { 3 - 4 } & & $-\mathrm{C}=$ O-(alpha \& beta unsaturated) & 1712 \\
\cline { 3 - 4 } & & Aromatic C=C Stretch & 1586 \\
\cline { 3 - 4 } & & C=O(Carboxylic acid) & 1742 \\
\hline & & C-N stretch amine & 1220 \\
\hline & & C-H stretch alkane & 2988,2834 \\
\hline
\end{tabular}

Table 4: Characteristic IR absorption of functional groups for drug and Excipients interaction

\begin{tabular}{|c|c|c|c|}
\hline Sr. No. & Particulars & Functional Groups & Characteristic Peaks $\left(\mathbf{c m}^{-\mathbf{1}}\right)$ \\
\hline \multirow{3}{*}{1} & Indomethacin + Excipients & $\mathrm{C}-\mathrm{O}$ stretching & 1115. \\
\cline { 3 - 4 } & & $\mathrm{O}-\mathrm{H}$ & 2765,2739 \\
\cline { 3 - 4 } & & $\mathrm{C}-\mathrm{Cl}$ stretching & 802 \\
\cline { 3 - 4 } & & $\mathrm{C}-\mathrm{O}$ stretching ether & 1260,1066 \\
\cline { 3 - 4 } & & Aromatic C=C Stretch & 1583 \\
\cline { 3 - 4 } & & $\mathrm{C}=\mathrm{O}$ (Carboxylic acid) & 1748 \\
\hline & & $\mathrm{C}-\mathrm{H}$ stretching alkane & 2800,2900 \\
\hline & & -C=O-(alpha \& beta unsaturated) & 1713 \\
\hline & & Aromatic C=C Stretch & 1583 \\
\hline
\end{tabular}

The powder mixtures prepared for compression of floating tablets were evaluated for their flow properties. Angle of repose was in the range of 21.12- 29.94 . Tapped density was found to be in the range of 0.50 $0.62 \mathrm{~g} / \mathrm{ml})$. Carr's index was in the range of $6.37-12.37$ and Hausner's ratio was in the range of 1.06-1.13 for the powder mixture of different formulation. All the result indicated that, the powder blends possess good flowability and compressibility properties. (Table 5).

Table 5: Preformulation parameters for powder blend

\begin{tabular}{|c|c|c|c|c|c|}
\hline Batch & $\begin{array}{c}\text { Bulk density } \\
\mathbf{( g m / m l})\end{array}$ & $\begin{array}{c}\text { Tap density } \\
(\mathbf{g m} / \mathbf{m l})\end{array}$ & Carr's index & $\begin{array}{c}\text { Hausner's } \\
\text { ratio }\end{array}$ & Angle of repose \\
\hline $\mathrm{F}_{1}$ & $0.512 \pm 0.065$ & $0.575 \pm 0.045$ & $10.95 \pm 0.75$ & $1.123 \pm 0.84$ & $26.28 \pm 0.25$ \\
\hline $\mathrm{F}_{2}$ & $0.530 \pm 0.054$ & $0.598 \pm 0.054$ & $11.37 \pm 0.45$ & $1.122 \pm 0.48$ & $26.97 \pm 0.43$ \\
\hline $\mathrm{F}_{3}$ & $0.570 \pm 0.035$ & $0.616 \pm 0.065$ & $7.46 \pm 0.36$ & $1.087 \pm 0.59$ & $27.33 \pm 0.56$ \\
\hline $\mathrm{F}_{4}$ & $0.578 \pm 0.046$ & $0.620 \pm 0.035$ & $6.77 \pm 0.75$ & $1.072 \pm 0.23$ & $29.94 \pm 0.47$ \\
\hline $\mathrm{F}_{5}$ & $0.425 \pm 0.025$ & $0.485 \pm 0.025$ & $12.37 \pm 0.35$ & $1.141 \pm 0.19$ & $22.92 \pm 0.38$ \\
\hline $\mathrm{F}_{6}$ & $0.470 \pm 0.015$ & $0.502 \pm 0.065$ & $6.37 \pm 0.26$ & $1.068 \pm 0.54$ & $23.21 \pm 0.74$ \\
\hline $\mathrm{F}_{7}$ & $0.417 \pm 0.075$ & $0.471 \pm 0.054$ & $11.46 \pm 0.45$ & $1.129 \pm 0.62$ & $21.12 \pm 0.58$ \\
\hline $\mathrm{F} 8$ & $0.421 \pm 0.048$ & $0.478 \pm 0.055$ & $11.92 \pm 0.76$ & $1.135 \pm 0.86$ & $22.24 \pm 0.59$ \\
\hline $\mathrm{F}_{9}$ & $0.445 \pm 0.067$ & $0.487 \pm 0.065$ & $8.62 \pm 0.15$ & $1.094 \pm 0.46$ & $21.22 \pm 0.62$ \\
\hline
\end{tabular}

The weight of the sample tablets varied between 246$249 \mathrm{mg}$. The variation in weight was within the range of $\pm 5 \%$, Complying with pharmacopoeial specifications, The hardness of different formulations was found to be 4.3-4.5 Kg/cm ${ }^{2}$, indicating satisfactory mechanical strength. The friability was below $1 \%$ for all the formulations, which is an indication of good mechanical resistance of the tablet. Diameter of tablets were measured and found in the range of 9.9 to $10 \mathrm{~mm}$ and Thickness of the tablets were found in the range of 2.9 to $3 \mathrm{~mm}$.

Floating lag time varied between 1.0-5.0 minutes. Floating property of the tablet is the governed by the swelling (hydration) of the tablet, when it contacts with the gastric fluid which in turn in results in increase in the bulk volume and pressure of internal voids in the centre of the tablet. Floating properties of the tablets could be improved with gas generating agent which is sodium bi carbonate. It generates gas when it comes in with an acidic environment of the stomach. This gas entraps into the matrix of water soluble of polymers and the formulation floats in acidic environment of the stomach. As the concentration of the HPMC increased, the swelling of the tablet increased, but the drug release decreased.

In vitro drug release data of all the floating formulation was subjected to goodness of fit test by linear regression analysis according to Zero order, First order, Higuchi, Korsmeyer-peppas models to ascertain the mechanism of drug release. The result of in vitro percentage drug release and linear regression analysis including 
regression coefficients are summarized in (Table 7, 8 and plots shown in Figure 3 \& 4-15).

From the above data, Among all the design Batches of tablet F6 was taken as on optimized batch for tablet optimization, Because F6 shows less friability <1, good hardness $4.5 \mathrm{~kg} / \mathrm{cm}^{2}$, less floating lag time $2.5(\mathrm{~min})$. (Table 6)

Table 6: Tablet diameter, Tablet thickness, Hardness, Friability and Weight Variation:

\begin{tabular}{|l|l|l|l|l|l|l|l|}
\hline Formulations & $\begin{array}{l}\text { Tablet } \\
\text { Diameter } \\
(\mathbf{m m})\end{array}$ & $\begin{array}{l}\text { Thickness } \\
(\mathbf{m m})\end{array}$ & $\begin{array}{l}\text { Hardness } \\
\left(\mathbf{K g} / \mathbf{c m}^{2}\right)\end{array}$ & $\begin{array}{l}\text { Friability } \\
(\boldsymbol{\%})\end{array}$ & $\begin{array}{l}\text { Weight } \\
\text { variation } \\
(\mathbf{m g})\end{array}$ & $\begin{array}{l}\text { Floating lag } \\
\text { time (min) }\end{array}$ & $\begin{array}{l}\text { Drug content } \\
(\boldsymbol{\%})\end{array}$ \\
\hline F1 & $9.98 \pm 0.04$ & $2.98 \pm 0.06$ & $4.5 \pm 0.08$ & $0.23 \pm 0.06$ & $248 \pm 6.66$ & 4.5 & $99.20 \pm 0.39$ \\
\hline F2 & $9.99 \pm 0.03$ & $2.97 \pm 0.07$ & $4.3 \pm 0.16$ & $0.21 \pm 0.06$ & $249 \pm 6.90$ & 5.0 & $98.45 \pm 0.25$ \\
\hline F3 & $10.0 \pm 0.00$ & $2.98 \pm 0.06$ & $4.4 \pm 0.08$ & $0.25 \pm 0.19$ & $246 \pm 6.73$ & 4.6 & $99.80 \pm 0.20$ \\
\hline F4 & $10.0 \pm 0.00$ & $2.98 \pm 0.06$ & $4.3 \pm 0.14$ & $0.32 \pm 0.03$ & $248 \pm 6.66$ & 3.0 & $98.30 \pm 0.45$ \\
\hline F5 & $9.99 \pm 0.03$ & $3.00 \pm 0.00$ & $4.5 \pm 0.08$ & $0.42 \pm 0.07$ & $249 \pm 6.90$ & 2.8 & $97.80 \pm 0.60$ \\
\hline F6 & $9.98 \pm 0.04$ & $2.98 \pm 0.06$ & $4.5 \pm 0.08$ & $0.08 \pm 0.01$ & $248 \pm 6.66$ & 2.5 & $98.65 \pm 0.25$ \\
\hline F7 & $10.0 \pm 0.00$ & $3.00 \pm 0.00$ & $4.3 \pm 0.14$ & $0.34 \pm 0.06$ & $246 \pm 6.73$ & 1.0 & $98.60 \pm 0.35$ \\
\hline F8 & $9.99 \pm 0.03$ & $2.97 \pm 0.07$ & $4.4 \pm 0.08$ & $0.23 \pm 0.06$ & $249 \pm 6.90$ & 1.2 & $98.75 \pm 0.25$ \\
\hline F9 & $10.0 \pm 0.00$ & $3.00 \pm 0.00$ & $4.5 \pm 0.08$ & $0.11 \pm 0.05$ & $249 \pm 6.90$ & 1.5 & $99.50 \pm 0.20$ \\
\hline
\end{tabular}

It can be seen that optimized formulation F6 has Zero order, Higuchi and peppas model was fitted. From that data,It was evident that the drug Release by non-fickian diffusion mechanism. Because the value of $r^{2}$ of Zero order, Higuchi's and peppas were 0.991,0.889 and 0.972 accordingly and ' $n$ ' value of peppas Equation was 0.903 . This data reveals the drug release follows non fickian diffusion Mechanism.(Table 8 and fig. 4-15)

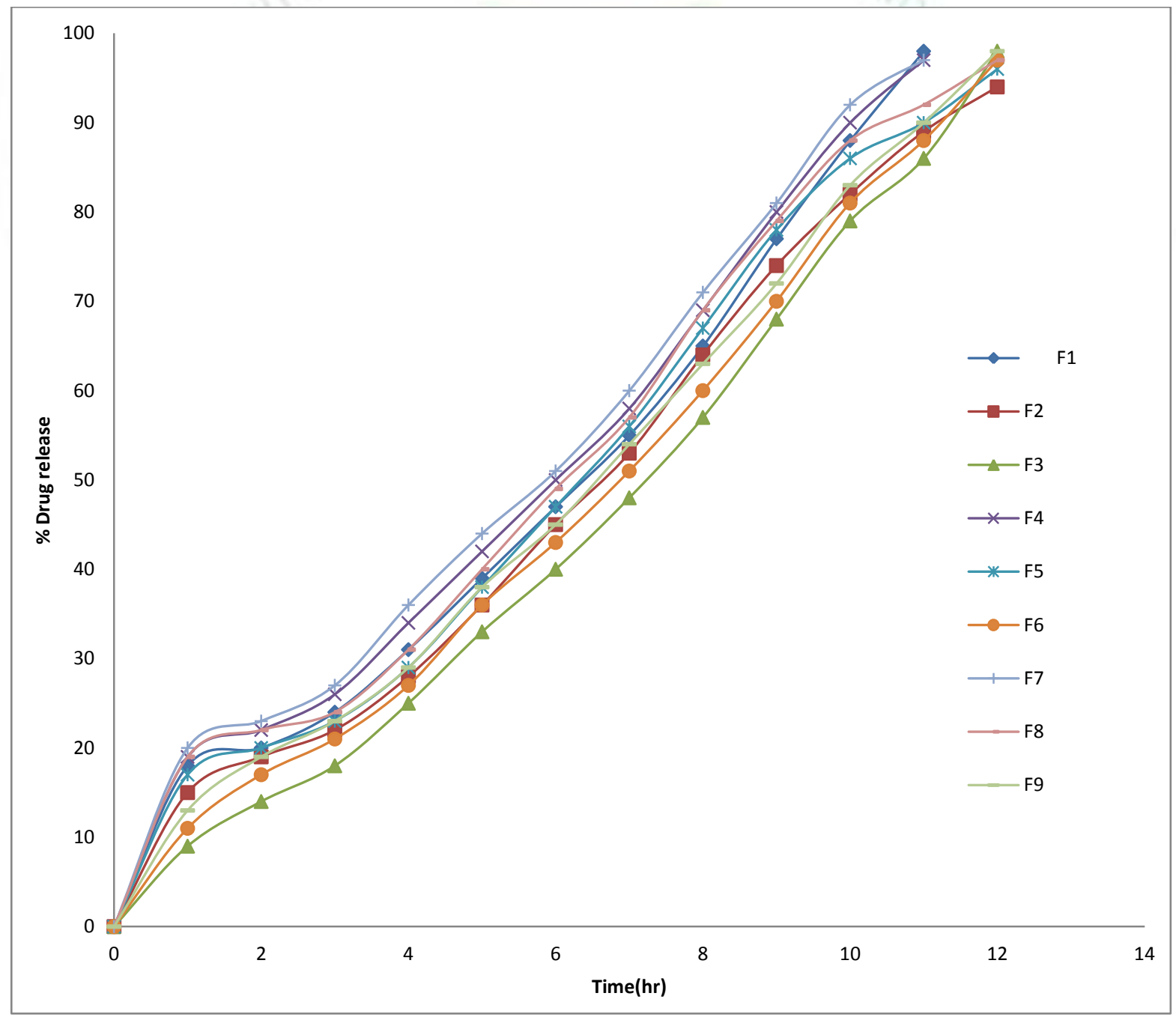

Figure 3: Percent drug release of Batches F1 to F9. 
Table 7: Release kinetics of batches F1 to F9

\begin{tabular}{|c|c|c|c|c|c|c|}
\hline \multirow{2}{*}{ Formulations } & \multicolumn{4}{|c|}{ Regression coefficient $\left(R^{2}\right)$} & \multirow{2}{*}{$\begin{array}{c}\text { Release } \\
\text { exponent }(n)\end{array}$} & \multirow{2}{*}{$\begin{array}{l}\text { Drug release } \\
\text { mechanism }\end{array}$} \\
\hline & Zero order & First order & Higuchi & $\begin{array}{c}\text { Korsmeyer- } \\
\text { Peppas }\end{array}$ & & \\
\hline F1 & 0.980 & 0.053 & 0.880 & 0.916 & 0.763 & Non-fickian transport \\
\hline F2 & 0.989 & 0.060 & 0.896 & 0.943 & 0.821 & Non-fickian transport \\
\hline F3 & 0.986 & 0.058 & 0.868 & 0.947 & 0.998 & Non-fickian transport \\
\hline F4 & 0.983 & 0.044 & 0.900 & 0.928 & 0.726 & Non-fickian transport \\
\hline F5 & 0.986 & 0.069 & 0.903 & 0.927 & 0.784 & Non-fickian transport \\
\hline F6 & 0.991 & 0.057 & 0.889 & 0.972 & 0.903 & Non-fickian transport \\
\hline F7 & 0.972 & 0.050 & 0.915 & 0.936 & 0.715 & Non-fickian transport \\
\hline F8 & 0.988 & 0.089 & 0.884 & 0.856 & 0.766 & Non-fickian transport \\
\hline F9 & 0.993 & 0.080 & 0.901 & 0.967 & 0.849 & Non-fickian transport \\
\hline
\end{tabular}

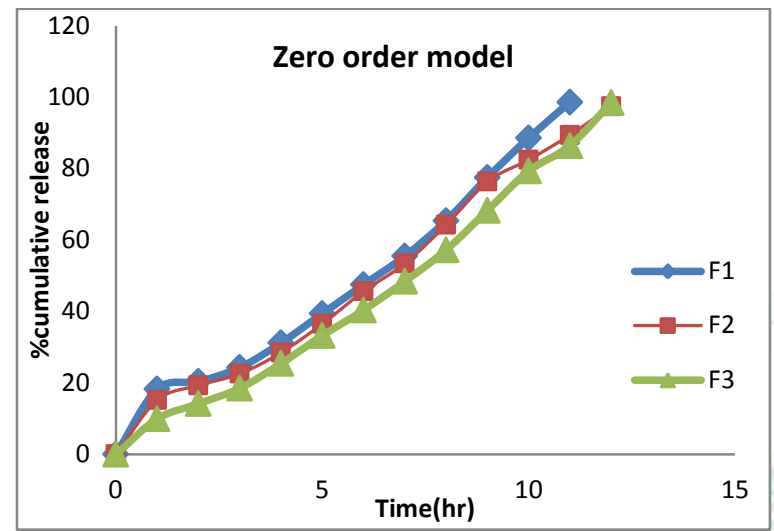

Figure 4: \% Cumulative amount of drug release v/s time of zero order kinetic(F1-F3)

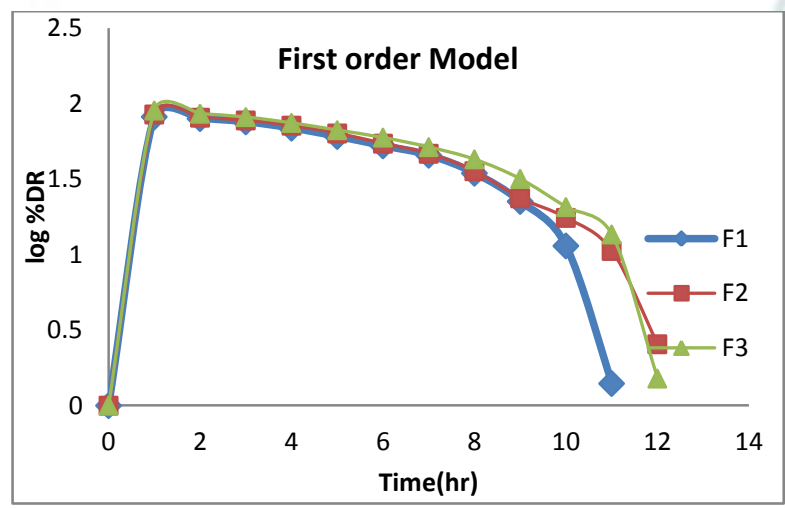

Figure 5: \% Log cumulative percent drug remaining v/s time of First order kinetic(F1-F3)

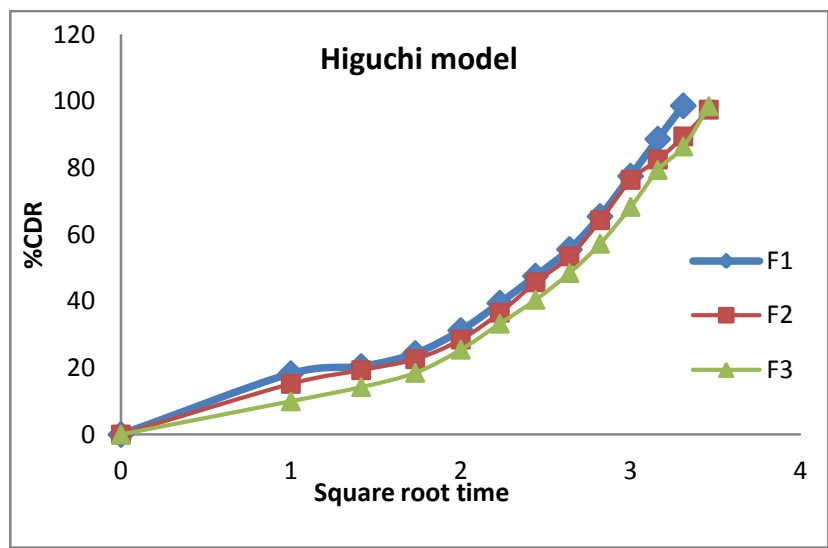

Figure 6: Cumulative percent drug release v/s the square root of time for higuchi model kinetics(F1-F3)

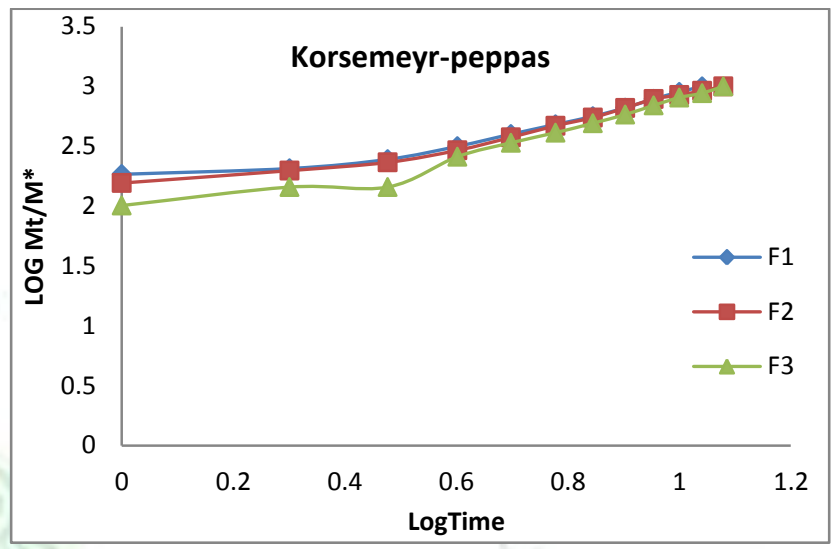

Figure 7: Log cumulative percent of drug released v/s log time for korsemeyr-peppas kinetics

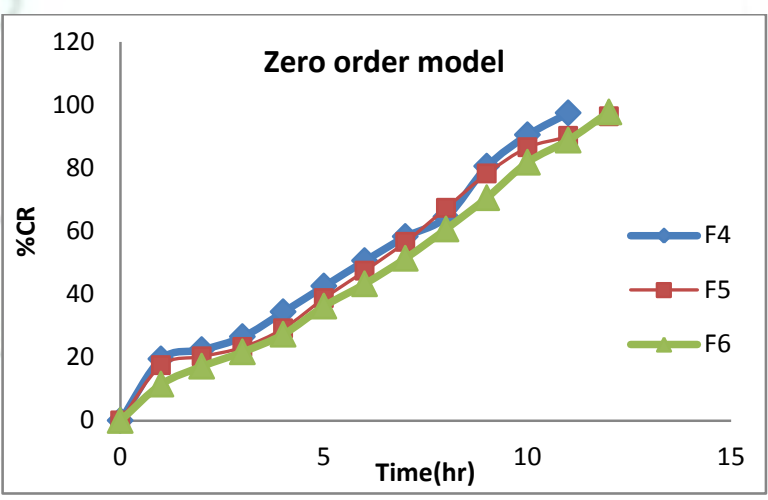

Figure 8: \% Cumulative amount of drug release v/s time of zero order kinetic (F4-F6)

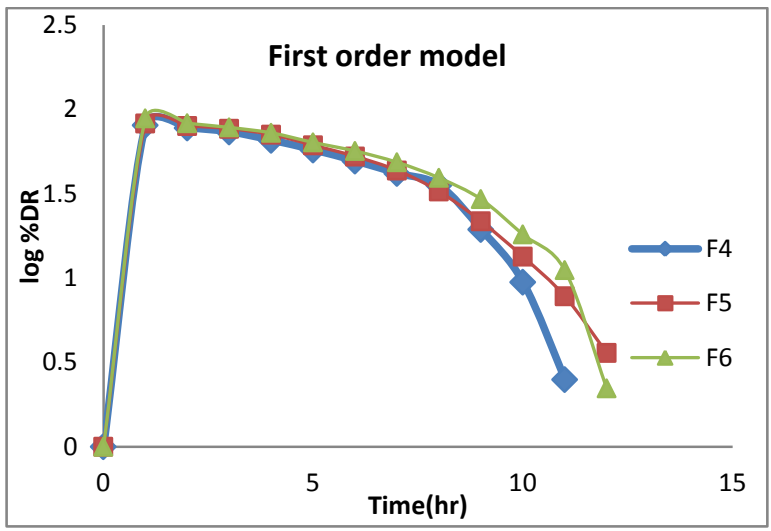

Figure 9: \% Log cumulative percent drug remaining v/s time of First order kinetic (F4-F6) 


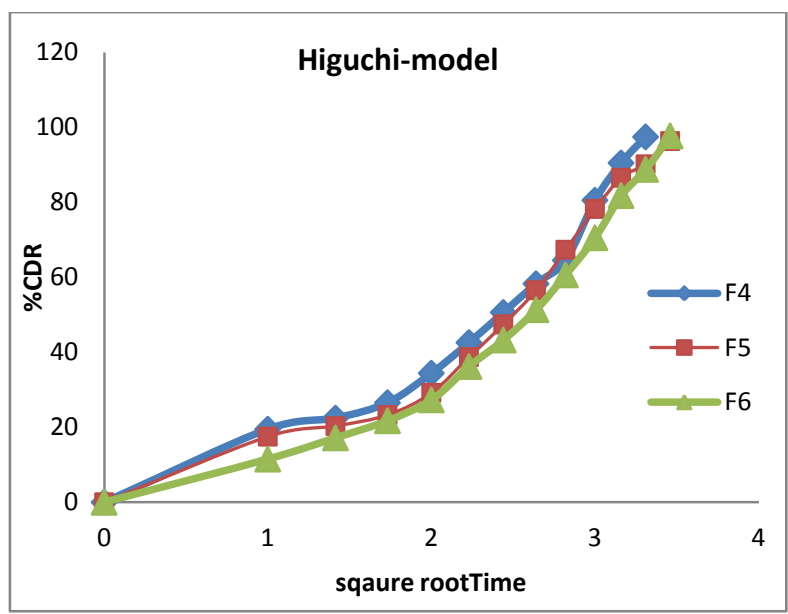

Figure 10: Cumulative percent drug release v/s the square root of time for higuchi model kinetics(F4-F6)

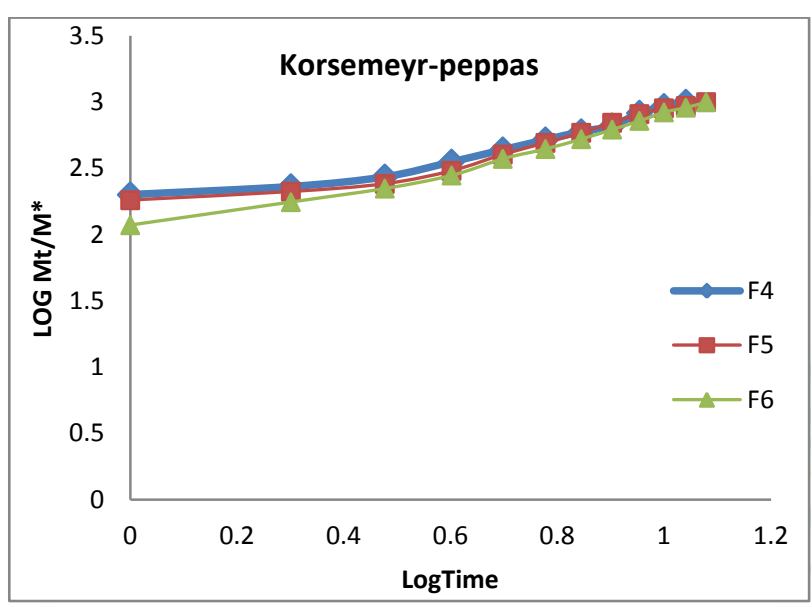

Figure 11: Log cumulative percent of drug released v/s log time for korsemeyr-peppas kinetics.

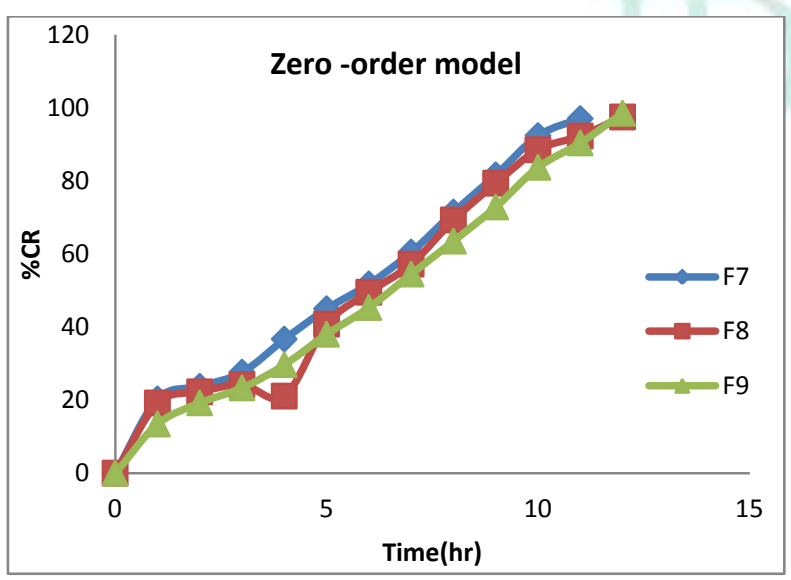

Figure 12: \% Cumulative amount of drug release v/s time of zero order kinetic(F7-F9).

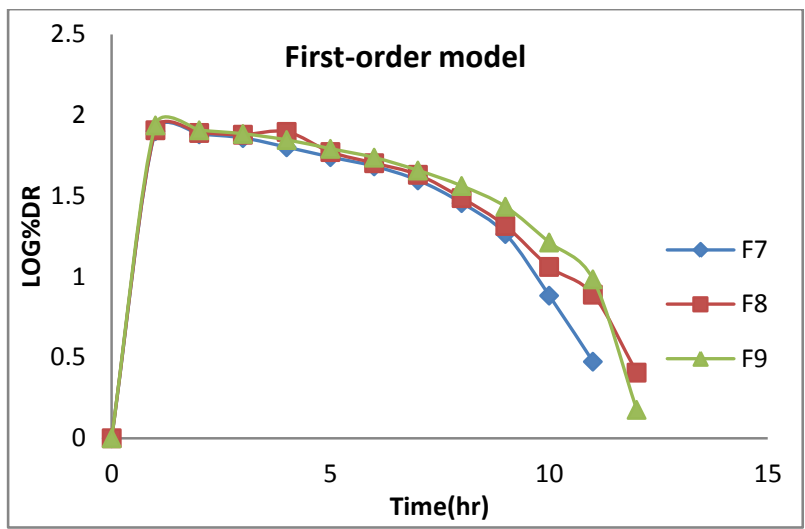

Figure 13: \% Log cumulative percent drug remaining v/s time of First order kinetic

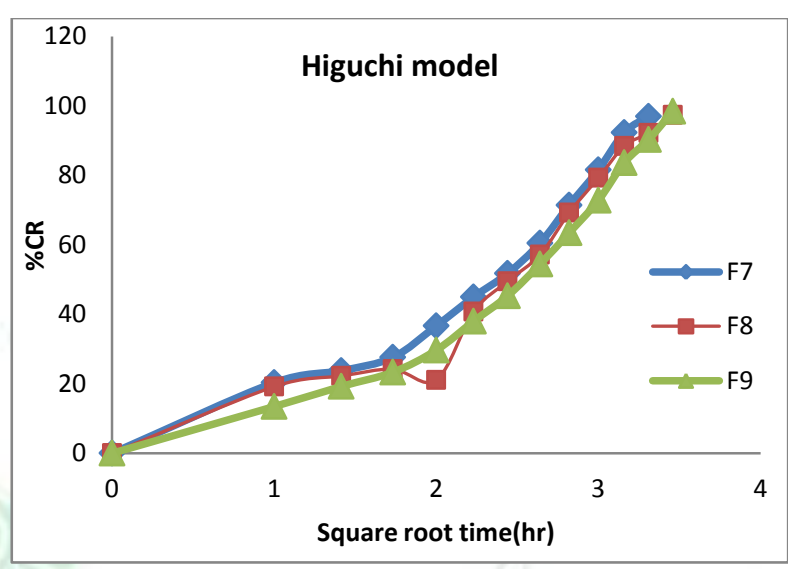

Figure 14: Cumulative percent drug release v/s the square root of time for higuchi model kinetics

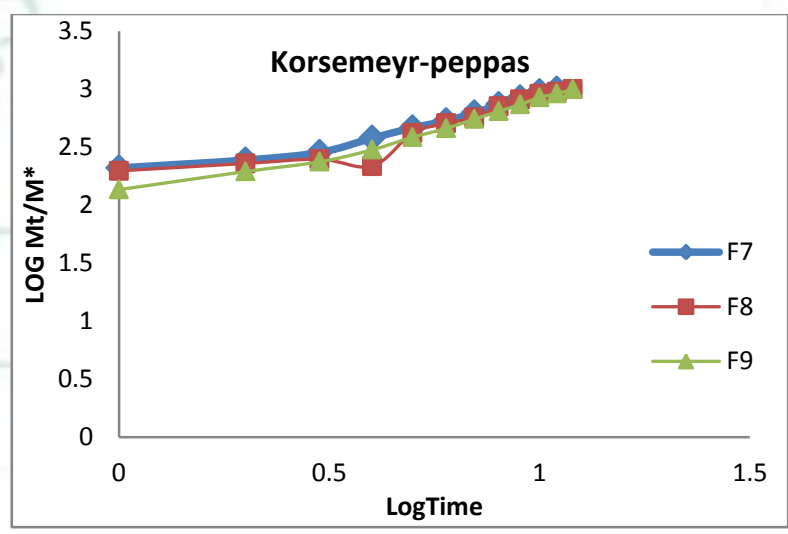

Figure 15: Log cumulative percent of drug released v/s log time for korsemeyr-peppas kinetics

Stability of optimized formulation (F-6) was performed for 1 and 3 month. In-vitro drug release study shown (Table 9) after 1 and 3 month, the drug release for 12 hrs obtained within range of targeted release profile and there was no drastic change in drug content, weight, floating lag time, friability, floating time, \% Cumulative drug release. It showed that there was no change in the formulation after 1 and 3 month. It indicates that prepared formulation was stable. 
Table 8: Physical evaluation parameters of formulation F6 during stability study

\begin{tabular}{|c|c|c|c|c|c|c|}
\hline $\begin{array}{c}\text { Sampling Time } \\
\text { Interval } \\
\text { (Months) }\end{array}$ & $\begin{array}{c}\text { Weight } \\
(\mathbf{~ m g})\end{array}$ & $\begin{array}{c}\text { Floating Lag } \\
\text { Time (min) }\end{array}$ & $\begin{array}{c}\text { Floating } \\
\text { Time } \\
\text { (Hrs.) }\end{array}$ & \% Friability & $\begin{array}{c}\text { Drug Content } \\
\text { uniformity }\end{array}$ & \% CDR \\
\hline Initial study & $248 \pm 6.66$ & 2.5 & $>12$ & $0.08 \pm 0.01$ & $98.65 \pm 0.25$ & $97.78 \pm 3.18$ \\
\hline 1 Month & $248 \pm 6.60$ & 2.0 & $>12$ & $0.06 \pm 0.05$ & $98.37 \pm 0.30$ & $97.78 \pm 3.12$ \\
\hline 3 Months & $248 \pm 6.70$ & 2.3 & $>12$ & $0.10 \pm 0.02$ & $98.10 \pm 0.15$ & $97.78 \pm 3.22$ \\
\hline
\end{tabular}

\section{CONCLUSION}

The floating tablets for indometahcin (F1-F9) were successfully prepared using HPMC 5cps matrix forming polymer and Sodium bi carbonate as gas generating agent by wet granulation techniques. The optimized formulation F6 has shown better sustained drug release and which has good floating properties. The release profile of optimized formula, fitted best to korsemeyrpeppas model with $R^{2}$ value of 0.972 . as the ' $n$ ' value for korsemeyr-peppas model was found to be 0.903 it follows non-fickian diffusion mechanism. It shown has good stability at storage condition.

\section{REFERENCES}

1. Chikhalikar SS and Wakade RB: Floating Drug Delivery System - An Approach to Oral Controlled Drug Delivery. International Journal of PharmTech Research 2012; 4(4)1812-26.

2. Tripathi GK, Singh S. Formulation and In vitro evaluation of $\mathrm{pH}$ sensitive oil entrapped polymeric blended buoyant beads of Amoxicillin. Scholars Research Library. 2010; 2(2):31- 38 .

3. Vedha H, Chaudhary J. The recent developments on gastric floating drug delivery system: An overview. Int $\mathrm{j}$ pharm tech res. 2010; 1(2):524-34.

4. Shah SH, Patel JK, Patel NV. Stomach specific floating drug delivery system: A review. Int J Pharm Tech Res. 2009 Jul; 1(3):623-33.

5. Gopalakrishnan S, Chenthilnathan A. Floating drug delivery systems: A Review. Journal of Pharmaceutical Science and Technology. 2011; 3(2):548-54.

6. Colombo P, Santi P, Bettini R, Brazel CS, Peppas NA. Drug release from swelling-controlled Systems. Handbook of pharmaceutical controlled release technology. 2000; 9:183-209.

7. Shruti S. A review on: recent advancement of stomach specific floating drug delivery system. International Journal of Pharmaceutical \& Biological Archive. 2012; 2(6).

8. Nayak AK, Malakar J, Sen KK. Gastroretentive drug delivery technologies Current Approaches and future potential. Journal of Pharmaceutical Education and Research. 2010; 1(2):1.

9. Gupta P, Gnanarajan PK. Floating Drug Delivery System: A Review. International Journal of Pharma Research \& Review. 2015; 4(8):37-44.

10. Kamalakkannan V, Puratchikody A, Prasanth VV, Masilamani K. Enhancement of Drugs Bioavailability by Floating Drug Delivery System-A Review. International Journal of Drug Delivery. 2011; 3(4):558.

11. Dubey J, Verma N. Floating drug delivery system: a review. International Journal of Pharmaceutical Sciences and Research. 2013; 4(8):2893.

12. Shah SH, Patel JK, Patel NV. Stomach specific floating drug delivery system: A review. Int $\mathrm{J}$ Pharm Tech Res. 2009; (3):623-33.

13. Pare A, Yadav SK, Patil UK. Formulation and evaluation of effervescent floating tablet of Amlodipine besylate. Research journal of pharmacy and technology. 2008; 1(4):526-30.

14. El-Kamel AH, Sokar MS, Al Gamal SS, Naggar VF. Preparation and evaluation of ketoprofen floating oral delivery system. International journal of pharmaceutics.2001; 220(1):13-21.

15. Narang N. An updated review on: floating drug delivery system (FDDS). Int J App Pharm. 2011; 3(1):1-7.

16. Mathur P, Saroha K, Syan N, Verma S, Nanda S, Valecha V. An overview on recent Advancements and developments in gastroretentive buoyant drug delivery system. Der Pharmacia Sinica. 2011; 2(1):161-9.

17. Srikanth MV, Rao NS, Sunil SA, Ram BJ, Kolapalli VR. Statistical design and Evaluation of a propranolol $\mathrm{HCl}$ gastric floating tablet. Acta Pharmaceutica Sinica B. 2012; 2(1):60-9.

18. Singh BN, Kim KH. Floating drug delivery systems: an approach to oral controlled drug Delivery via gastric retention. Journal of Controlled release. 2000; 63(3):23559.

19. Nama M, Gonugunta CS, Veerareddy PR. Formulation and evaluation of Gastroretentive Dosage forms of clarithromycin. AAPS PharmSciTech. 2008; 9(1):231.

20. Gopalakrishnan S, Chenthilnathan A. Floating drug delivery systems: A Review. Journal of Pharmaceutical Science and Technology. 2011; 3(2):548-54.

21. Vedha H, Chaudhary J. The recent developments on gastric floating drug delivery system: An overview. Int $\mathrm{j}$ pharm tech res. 2010; 1(2):524-34. 